\title{
Mycobacterium terrae
}

National Cancer Institute

\section{Source}

National Cancer Institute. Mycobacterium terrae. NCI Thesaurus. Code C86592.

A species of aerobic, Gram-positive, rod shaped bacteria assigned to the phylum Actinobacteria. This species is acid-fast, positive for nitrate reductase, tellurite reductase, catalase and Tween hydrolysis, and is negative for urease. M. terrae is found mainly in soil and on vegetables and can cause disease in the joints, tendons, lungs, and gastrointestinal and genitourinary tracts. 